\title{
Enzyme-Linked Immunosorbent Assay Using Vertical Micro Reactor Stack for the Detection of Biomolecules
}

\author{
Katsuhiro Matsui Non-member (Univ. of Hyogo) \\ Syohei Morimoto Non-member (Univ. of Hyogo) \\ Toshifumi Asano Non-member (Univ. of Hyogo) \\ Yoshiaki Ukita Student Member (Univ. of Hyogo) \\ Dai-ichiro Kato Non-member (Univ. of Hyogo) \\ Masahiro Takeo Non-member (Univ. of Hyogo) \\ Yuichi Utsumi Member (Univ. of Hyogo) \\ Seiji Negoro Non-member (Univ. of Hyogo)
}

Keywords : Microreactor, Enzyme Linked Immuno Sorvent Assay (ELISA), Syncrotron Radiation, Fluid Filter

Microreactors and micro total analysis system ( $\mu \mathrm{TAS})$ are recognized as powerful tools for genomics, proteomics, clinical diagnostics, and environmental testing. In this paper, we describe enzyme linked immunosorvent assay (ELISA) using a new microreactor with a vertical fluid flow operation. As shown in Fig. 1., this microreactor is composed of two reaction vessels stacked on the vertical lines through PMMA fluid filters $(\phi 3 \mathrm{~mm})$. The fluid filters constructed by deep X-ray lithography possess 2,100 pores $(\phi 40 \mu \mathrm{m})$, and have valve functions, which maintain liquid layer in each reaction vessel. In addition, the liquid can be selectively transferred by air pressure from upper vessel to lower, and vice versa.

As a model of ELISA using the microreactor, we planed to detect mouse immunoglobulin (IgG). We bound the goat anti-IgG antibody to the surface of the PMMA filters, and assayed the IgG by ELISA using anti-IgG antibody/ peroxidase conjugate (Fig. 2).

We found that the mouse $\operatorname{IgG}(100 \mathrm{ng} / \mathrm{ml})$ was quantitatively detected within 45 min of analytical period, which was ca. 1/3 of the period required for the conventional method using micro titer plate (Fig. 3).

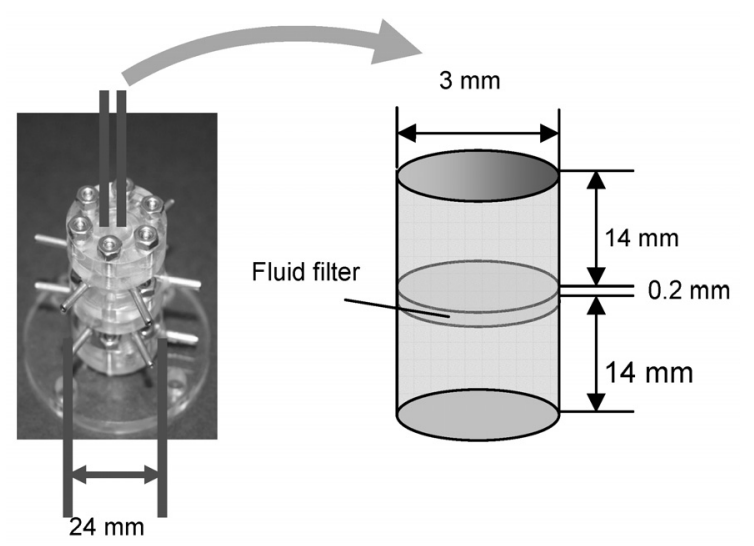

(a)

(b)

Fig. 1. (a) Outward appearance of the reactor which consist of two reservoirs. (b) Schematic illustration of fluid filter and reservoirs

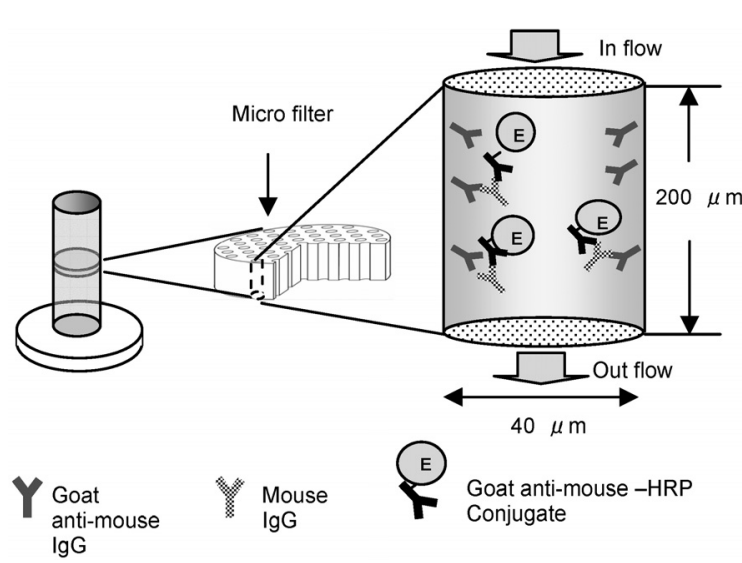

Fig. 2. Schematic illustration of the ELISA method on micro fluid filter

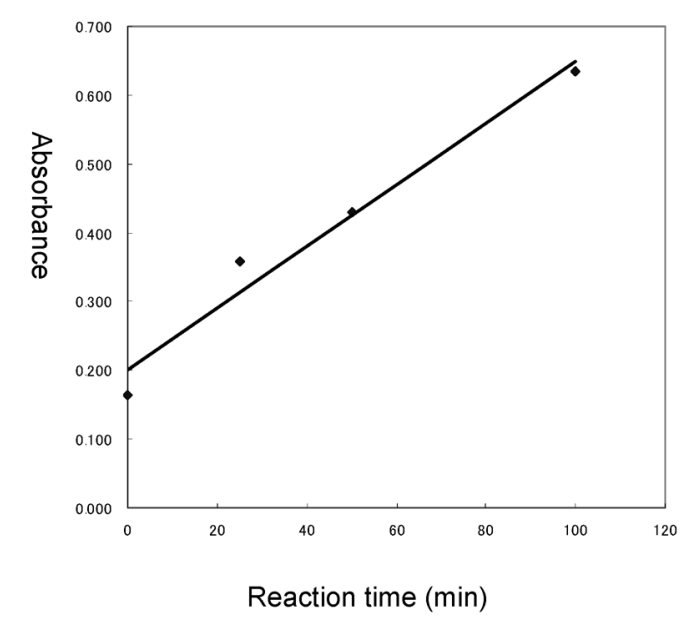

Fig. 3. Calibration curve of Mouse IgG 


\section{積層型マイクロリアクターを用いた}

\section{酵素免疫測定法による生体物質測定系の開発}

$\begin{array}{llll}\text { 非会員 松井 勝弘* } & \text { 非会員 森本 } & \text { 祥平* } \\ \text { 非会員 浅野 豪文** } & \text { 学生員 浮田 芳昭** } \\ \text { 非会員 加藤太一郎* } & \text { 非会員 武尾 } & \text { 正弘* } \\ \text { 正 員 内海 裕一** } & \text { 非会員 根来 誠司* }\end{array}$

\section{Enzyme-Linked Immunosorbent Assay Using Vertical Micro Reactor Stack for the Detection of Biomolecules}

Katsuhiro Matsui*, Non-member, Syohei Morimoto*, Non-member, Toshifumi Asano**, Non-member, Yoshiaki Ukita**, Student Member, Dai-ichiro Kato*, Non-member, Masahiro Takeo*, Non-member, Yuichi Utsumi**, Member, Seiji Negoro*, Non-member

Microreactors and micro total analysis system ( $\mu$ TAS) are recognized as powerful tools for genomics, proteomics, clinical diagnostics, and environmental testing. In this paper, we describe enzyme linked immunosorvent assay (ELISA) using a new microreactor with a vertical fluid flow operation. This microreactor is composed of two reaction vessels stacked on the vertical lines through PMMA fluid filters $(\phi 3 \mathrm{~mm})$. The fluid filters constructed by deep X-ray lithography possess 2,100 pores $(\phi 40$ $\mu \mathrm{m})$, and have valve functions, which maintain liquid layer in each reaction vessel. In addition, the liquid can be selectively transferred by air pressure from upper vessel to lower, and vice versa. As a model of ELISA using the microreactor, we planed to detect mouse immunoglobulin (IgG). We bound the goat anti-IgG antibody to the surface of the PMMA filters, and assayed the IgG by ELISA using anti-IgG antibody/ peroxidase conjugate. We found that the mouse IgG (100 $\mathrm{ng} / \mathrm{ml})$ was quantitatively detected within 45 min of analytical period, which was ca. 1/3 of the period required for the conventional method using micro titer plate.

キーワード : マイクロリアクター, 酵素免疫測定法, 放射光,

Keywords : Microreactor, Enzyme Linked Immuno Sorvent Assay (ELISA), Syncrotron Radiation, Fluid Filter

\section{1. はじめに}

2003 年にヒトゲノム配列の解読が完了した ${ }^{(1)}$ 。得られた ゲノム情報を病気の原因解明・治療・予防法の確立などに 役立てるためには，個々の遺伝子産物の機能解明，発現機 構に関して, 膨大な解析（ポストゲノム解析）が必要であ る。そのためには, 多数の遺伝子やタンパク質の機能を, 定量的かつ迅速に評価する手法の確立が重要な課題とな

\footnotetext{
* 兵庫県立大学大学院 工学研究科物質系工学専攻

T671-2201 兵庫県姫路市書写 2167

Graduate. School of Engineering, Univ. of Hyogo,

2167 Shosya, Himeji, Hyogo 671-2201

** 兵庫県立大学 高度産業科学技術研究所

T678-1205 兵庫県赤穂郡上郡光都 3-1-2

Laboratory of Advanced Science. and Technology for Industry, Univ. of Hyogo

3-1-2 Koto, Kamigori, Ako-gun, Hyogo 678-1205
}

$$
\text { る。 }
$$

近年，マイクロマシン技術を用いたマイクロリアクター や, $\mu$ TAS (Micro Total Analysis System の略)と呼ばれるシス テムの研究が注目されている(2)(3)。これらは数 $\mathrm{cm}$ 角程度の ガラスやプラスチック等の基板上に, 数十から数百 $\mu \mathrm{m}$ 程度 の流体流路を作製し, 小型化されたポンプ, バルブ, セン サなどを組み合わせた化学分析システムである。各要素を マイクロマシン技術によりダウンサイジングし, 基板上に 集積化することにより，材料原資の低減，使用試薬量の低 減が可能となる。また, 比界面積 (反応空間内における体 積辺りの反応表面積）の上昇, 分子拡散距離の微小化によ る拡散律速の反応速度上昇などの効果が期待できる。一方, 上記の微小化に伴う利点を活かして, DNA チップやプロテ インチップと呼ばれるアレイ状の反応デバイスに関する研 
究も盛んに行われている(4)(5)。

我々は, 既存の水平型マイクロリアクターやマイクロア レイとは異なった概念のシステム, すなわち, 垂直方向に 多段の単位化学反応操作が可能な積層型マイクロリアクタ 一の開発を行っている(6)(7)。本リアクターは，各反応槽が， 放射光微細加工により作製されたマイクロ流体フィルター で区切られた構造であり，以下の特徵を有する。i） 1 数 ミリメータの各リアクター内に, 高アスペクト比の微細貫 通孔が 1000 個以上集積された空間が構築されるため, 同微 細空間を反応場とすることで, 拡散律速反応速度の上昇が 期待できる。ii）反応液が流体フィルターを通過する際の ミキシング効果により, 複数成分の迅速混合が可能である。 iii）各素子を, 平面上に並べて高集積化することで，多検 体・多項目分析に対応しやすい。iv）システム全体の流路 長が短く，低圧で送液制御が可能であることから，装置全 体を小型化しやすい。

今回, 酵素免疫測定法（ELISA 法）を原理とした生体関 連物質測定系として，マウス免疫グロブリンを対象物質と し, 積層型マイクロリアクターへの適用について検討した ので，その結果を報告する。

\section{2. 積層型マイクロリアクターの概念と概要}

〈2·1〉積層型マイクロリアクターの概念＼cjkstart本研究で 用いた積層型マイクロリアクターの概念図を図 1 に示す。 試作したリアクター本体はアクリル樹脂製であり，直径は 約 $2.4 \mathrm{~cm}$ で反応部の直径は $3 \mathrm{~mm}$ である。リアクターは 2 層に積層されており，仕切りの役目と反応槽の役目を兼祆 る PMMA 製の流体フィルターで各槽を仕切っている。今回 評価した酵素免疫測定法にて物質を検出する際には，上槽 から試薬，サンプルを注入し，流体フィルター部位で溶液 を保持させ，フィルターに結合されている抗体とサンプル 中の抗原を反応させる。その後, 上槽部から空圧により反 応溶液を排出した後, フィルターの洗浄工程を経て, 発色

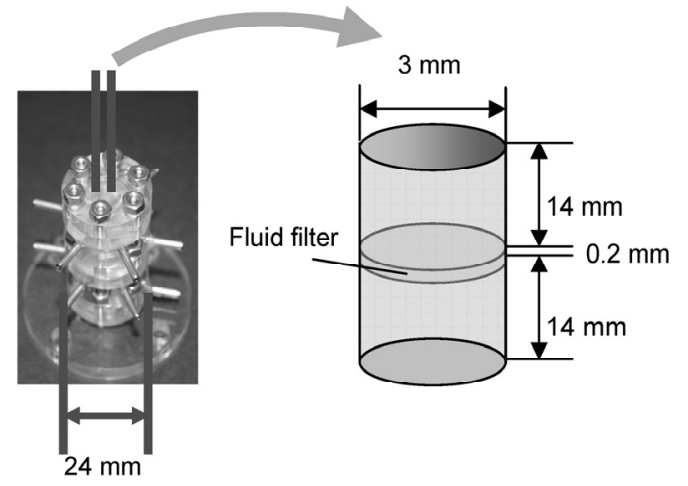

(a)

(b)

図 1 (a)二槽構成積層型マイクロリアクターの外観 (b)流 体フィルターと反応層の模式図

Fig. 1. (a) Outward appearance of the reactor which consist of two reservoirs. (b) Schematic illustration of fluid filter and reservoirs
基質を加えフィルター上に保持させた後, 反応終了後の発 色基質を圧力により下槽に送液する。下槽には光ファイバ 一分光光度計 USB2000 (Ocean Optics inc. : USA) を設置 し, 吸光度や蛍光強度等を測定する。このような縦方向に 構築した単一反応槽を今後更に微小化し，横方向から検出 することで，システム全体を立体的に配置出来るため，多 検体分析や多項目分析への応用が期待できる。また，本リ アクターは, 各ユニットで単位反応をアレンジすることが 可能である。従って, 精製・分離などの機能を有するユニ ットの挿入もでき, より複雑な工程を含む化学合成や, 生 化学反応プロセスへの応用も可能である。

〈2·2〉 PMMA(poly methyl methacrylate) 製流体フィル ター 将来的に, リアクターの反応槽直径を $1 \mathrm{~mm}$ 以下

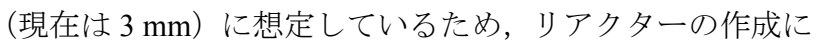
はマイクロ 3 次元加工技術を用いた。これは, X 線を活用 したマイクロ微細立方体デバイスの製造技術である LIGA プロセスに高エネルギー放射光を用いたリソグラフィー技 術を適用したものである。

本研究ではリアクター（反応槽） と高機能フィルターの 作製を行うために, $1 \mathrm{~mm}$ 以上の深い縦方向加工が必要とな る。それを可能にするのは $10 \mathrm{KeV}$ 以上の高エネルギー放射 光を用い, 各単位機能槽の形状や寸法に適合したマイクロ 3 次元加工技術の最適化を行う必要がある。我々は, ポリイ ミドを支持体とし, UV フォトレジスト法でX 線マスクを作 製した後，厚さ $200 \mu \mathrm{m}$ の PMMA 板の上に設置し，上部か ら放射光を照射し, その後現像を行い, PMMA 製流体フィ ルターを作製した。放射光は, 兵庫県立大学・放射光施設 (NewSUBARU) の LIGA 用ビームライン BL2, $11^{(8)(9)}$ を使用 した。完成した流体フィルターは, 厚さ $200 \mu \mathrm{m}$, 直径 $3 \mathrm{~mm}$ の PMMA 製フィルターに直径 $40 \mu \mathrm{m}$ の微細穴が約 2,100 個 貫通している（図 2)。放射光による加工の特徽として, よ りアスペクト比の大きいフィルターの作製が可能であり, ミリオーダーの厚みを有するフィルターの加工ができるこ とも確認している。

\section{3. 測定原理}

〈3-1〉 酵素免疫測定法（ELISA 法）の原理酵素免

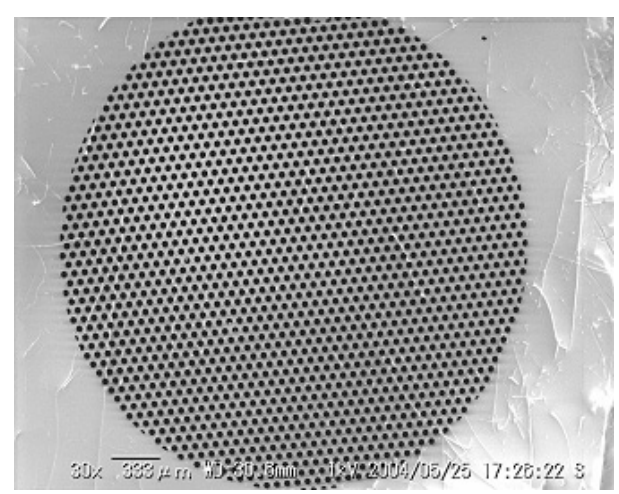

図 2 PMMA 製流体フィルターの SEM 写真

Fig. 2. The SEM image of the micro fluid filter 

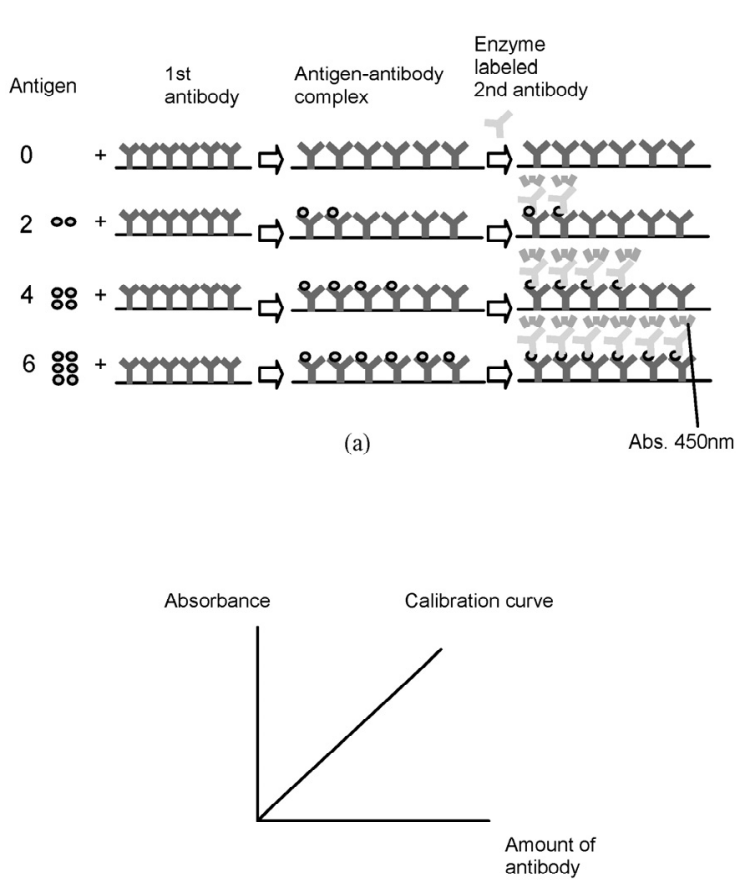

(b)

図 3 酵素免疫測定法（ELISA 法）の原理

(a) サンドイッチ法の模式図, (b) 検量線形状

Fig. 3. Schematic illustration of ELISA Method

疫測定法は, ELISA 法 (Enzyme Linked Immuno Sorvent Assay の略)とも呼ばれ，血中の抗体などを測定し，病気を診断す る臨床検査分野 ${ }^{(10)}$ や, 食品分野における食中毒菌の検出 ${ }^{(11)}$, また環境検査における環境污染物質の検出などに広く用い られている。酵素免疫測定法は, 酵素で標識された抗体 (ま たは抗原）と，対応する抗原（または抗体）との間で起こ る抗原抗体反応を利用したものである。元来，抗原抗体反 応とは，体の中に異物（抗原）が進入した際に，体内に存 在するリンパ球が，これを排除するために抗原と特異的に 結合する抗体を産生し, 無毒化する生体防御機構の一つで ある。抗原と抗体は 1 対 1 の関係で特異的に結合するので 酵素免疫測定法ではこの反応を利用して目的物質を検出す る。図 3 に酵素免疫測定法の概要を示す。通常, 蛋白質な どの分子量の大きい物質を測定する場合，反応固相表面に 固定化された抗体に抗原（被検物質）が結合し，さらに酵 素標識 2 次抗体が結合しサンドイッチ状の複合体を形成さ せた後，抗原の結合量を標識抗体の酵素活性（発色量）で 定量する方法であり，通常，サンドイッチ ELISA 法と呼ば れる。

\section{4. 実験方法}

〈4·1〉積層型マイクロリアクター及び PMMA 製抗体固 定化処理流体フィルター準備方法＼cjkstart積層型マイクロリア クターは 2 槽から構成されている。リアクター本体はアク リル樹脂で作製されており，上槽と下槽の間には PDMS 製 の緩衝材で挟まれた PMMA 製流体フィルターを設置すると いう構成になっている（図 1)。前処理として，サンプル， 2

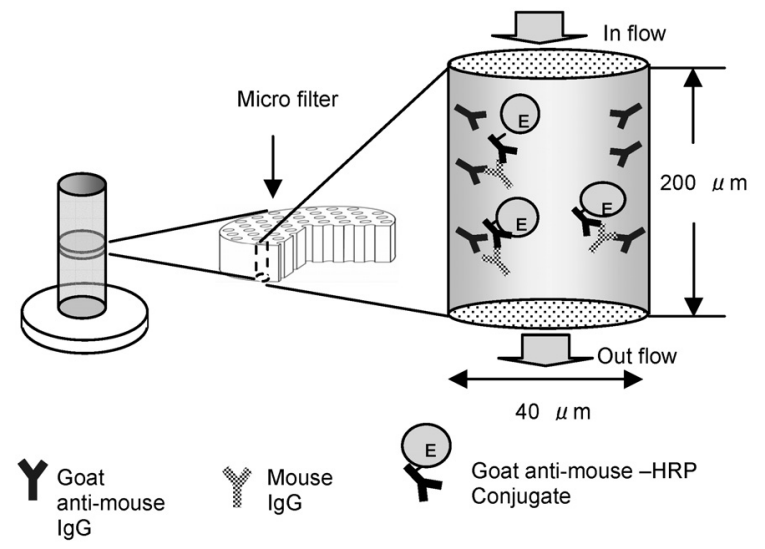

図 4 流体フィルターを用いた酵素免疫測定法概要

Fig. 4. Schematic illustration of the ELISA method on micro fluid filter

次抗体の非特異的吸着を防ぐために流路に相当する部分を リアクター, PDMS (Polydimethylsiloxane) 製緩衝材共に, 2\% BSA 溶液 (0.1 M NaCl 10mM リン酸緩衝液 ( $\mathrm{pH} 7.0)$ に溶解) に浸し， $4^{\circ} \mathrm{C}$ で一晚浸漬しておいた。また，放射光を用いて 作製した流体フィルターは， $0.5 \mathrm{mg} / \mathrm{ml} \quad(0.1 \mathrm{M} \mathrm{NaCl} 10 \mathrm{mM}$ リン酸緩衝液 ( $\mathrm{pH}$ 7.0) に溶解) の抗マウス $\operatorname{IgG}$ (Anti-Mouse $\operatorname{IgG}$ (Goat) : MBL 社製) に $4{ }^{\circ} \mathrm{C}$ で一晚浸漬し, 抗体を物理吸 着によりフィルターの各微細工内壁および上下表面に固定 化した（図 4)。リアクターと流体フィルターの前処理終了 後, 抗体固定化処理を行った流体フィルターをリアクター にセットし, 洗浄液 $[0.05 \%$ Tween $20 / 10$ mM リン酸緩衝液 (pH 7.0)] にて流路を洗浄した。

〈4·2〉 ELISA 測定系反応操作 実際の測定操作を以 下に示す。〈4・1〉節で示した手順どおり, リアクターと抗 体感作済みフィルターをセットした後, 空気圧により流路 を乾燥させた。サンプル $50 \mu \mathrm{l}$ を加え, $37{ }^{\circ} \mathrm{C} 1$ 時間静置し た。反応終了後, サンプル溶液を空気圧により下槽から排 出し, その後, 洗浄液 $2.5 \mathrm{ml}$ を加え, 流路を洗浄した。酵 素標識 2 次抗体 $50 \mu \mathrm{l}$ を加え, $37{ }^{\circ} \mathrm{C}, 1$ 時間静置した後, 溶液を排出し, 洗浄液 $2.5 \mathrm{ml}$ で流路を洗浄した。基質溶液 [0.0006\% 過酸化水素水を含む， $333 \mathrm{nM} \mathrm{TMBZ} \mathrm{(3，3，，5，}$ 5'-tetramethylbendizine）溶液 / 0.1 M 䣷酸緩衝液（pH5.0）] を $70 \mu \mathrm{l}$ 加え, 室温暗所 20 分静置した後, $1 \mathrm{~N}$-硫酸を $30 \mu \mathrm{l}$ 加え, 発色反応を停止させた後, 溶液を下槽へ空気圧で移 送し, $450 \mathrm{~nm}$ の吸光度を光ファイバー吸光光度計にて測定 した。

〈4·3〉 ELISA 測定系検証実験 PMMA 製流体フィル ターを使用したマイクロリアクターにて ELISA 測定系が行 えるかについて検証した。PMMA 製流体フィルターに 1 次 抗体を固定化した場合と, 固定化しない場合の各々の条件 に対し, サンプル（マウス IgG $25 \mathrm{ng} / \mathrm{ml}$ ) を加えた場合, 加 えない場合の条件を設定し, 計 4 条件でアッセイを行った

(図 5)。仮に，1 次抗体がフィルター上に感作されていれ ば, 1 次抗体を感作処理したフィルターで, サンプルを加え た場合にのみ，サンプル結合に依存した発色が期待できる。 


\section{$\langle 4 \cdot 4\rangle$ 反応固相表面とサンプル間の反応時間測定実験}

抗マウス $\operatorname{IgG}$ 抗体固定化済み流体フィルターをセットし, 流路洗浄済みのリアクターに, マウス $\mathrm{IgG}$ 抗体を添加した。 $37{ }^{\circ} \mathrm{C} に$ 設定した恒温槽にリアクターを入れた。0 分から 2 時 間の間で反応時間条件を変化させた後, 洗浄工程を経て, 䤉 素標識抗マウス $\operatorname{IgG}$ 抗体を $37{ }^{\circ} \mathrm{C} 1$ 時間反応させた。この後, 発色反応を行い分光光度計にて䤉素活性の定量を行った。

〈4.5〉 サンプルと酵素標識 2 次抗体間の反応時間測定 実験抗体固定化フィルターをセットしたリアクター に, $50 \mathrm{ng} / \mathrm{ml}$ のマウス $\mathrm{IgG}$ を $50 \mu \mathrm{l}$ 添加し $37{ }^{\circ} \mathrm{C} \quad 1$ 時間反 応させた。洗浄工程を経て, 酵素標識抗マウス $\operatorname{IgG}$ 抗体と の反応時間を, 0 分から 2 時間の間で変化させ, 反応させた。 さらに, 発色反応を行い, 分光光度計にて酵素活性の定量 を行った。

〈4·6〉 検量線検討実験 抗体固定化フィルターをセ ットしたリアクターを 4 台準備した。マウス $\mathrm{IgG}$ を 0, 25, 50, $100 \mathrm{ng} / \mathrm{mL}$ に調製し， $50 \mu 1$ ずつ添加し $37{ }^{\circ} \mathrm{C} \quad 1$ 時間反応さ せた。反応終了後, 溶液を上槽から空気圧により下槽の排 出口から排出し, 洗浄液を上槽から $5 \mathrm{~mL}$ 流し込み, 下槽の 排出口から排出することによりリアクターを洗浄した。上 槽から空気を入れ溶液を完全に排出した後, 抗マウス $\operatorname{IgG}$ ヤギ IgG 溶液 $50 \mu \mathrm{l}$ を加え, フィルターが溶液に満たされる まで送液し, 保持した。 $37{ }^{\circ} \mathrm{C} 1$ 時間静置した後, 溶液を 排出し, 洗浄液 $5 \mathrm{ml}$ 流し込み, 下槽の排出口から排出寸る ことによりリアクターを洗浄した。発色基質 $70 \mu \mathrm{l}$ を加え, 室温暗所 20 分静置した後, 反応停止液 $30 \mu 1$ を加え, 反応 を停止後, 空気圧により反応液を下槽に送液し, 光ファイ バー分光光度計にて $450 \mathrm{~nm}$ の吸光度を測定した。

\section{5. 実験結果及び考察}

〈5·1〉 ELISA 測定系検証実験 PMMA 製流体フィル ターを用いた ELISA 測定結果を図 5 に示す。1 次抗体を固 定化した条件で，マウス IgG を加えなかった場合(a), マウ ス $\mathrm{IgG}$ を加えた場合(b)の吸光度 $\left(\mathrm{A}_{450}\right)$ の值を比較すると, (b)は(a) と比較して明瞭なシグナル差を生じており, 醳素標 識 2 次抗体がマウス $\operatorname{IgG}$ を介して結合したことを示してい る。また, 1 次抗体を固定化しない条件で, マウス $\operatorname{IgG}$ を加 えなかった場合(c), マウス IgG を加えた場合（d）共に, (b) と比較して明膫なシグナル差を生ずることは無かった。こ れは, (b)におけるシグナルが, 反応固相に結合した抗マウ ス IgG 抗体を固定化したことに起因することを意味する。 抗マウス IgG 抗体を表面に固定化しない場合(d)では，(b)の ようなシグナルを生じないことより，(b)のシグナルが，マ ウス $\operatorname{IgG}$ が反応固相表面に非特異的に結合し, 更に酵素標 識抗マウス $\operatorname{IgG}$ 抗体が結合した複合体由来でないというこ とを示唆する。以上の結果より，1）PMMA 製流体フィル ター上には抗マウス $\operatorname{IgG}$ 抗体が固定化されていること，2） 本マイクロリアクターを用いた ELISA 測定系により，マウ ス IgG の測定が可能であることが分かった。また，非特異 的吸着を抑えるためのブロッキング処理条件の検討によ
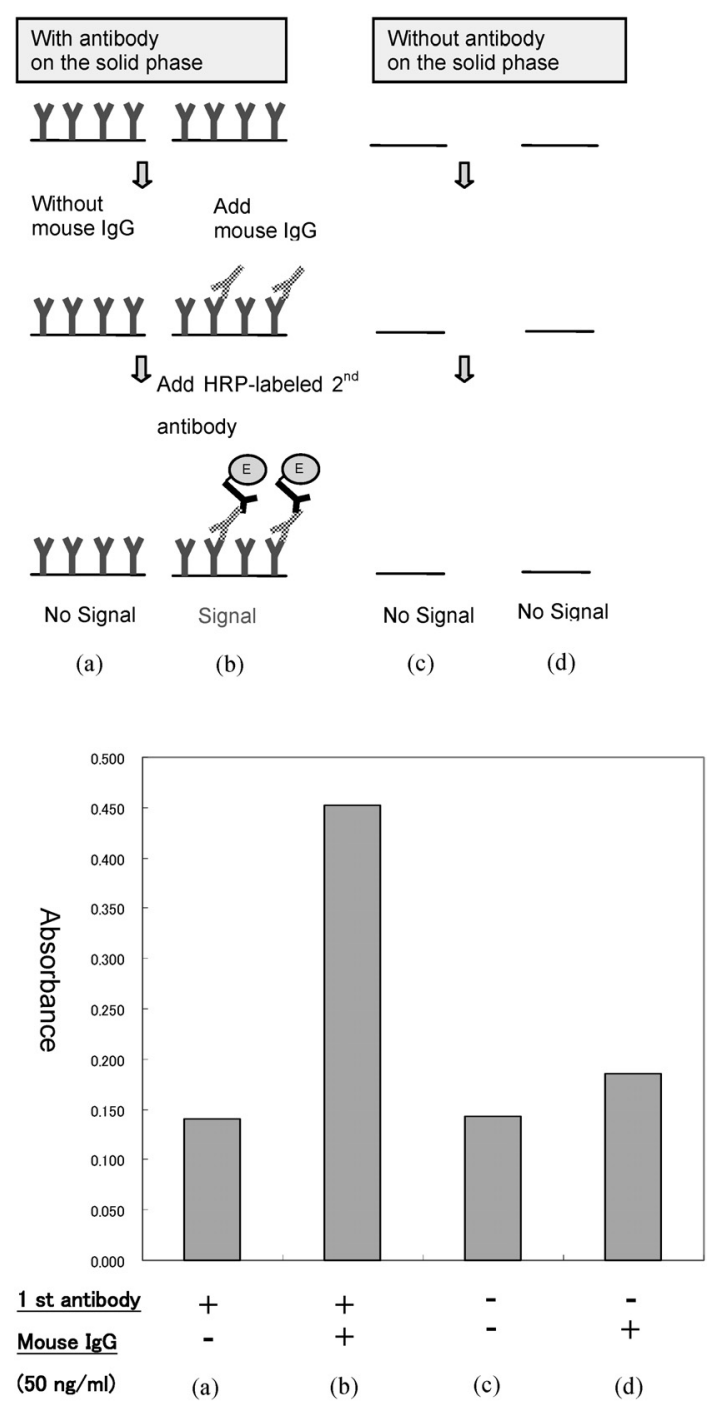

図 5 ELISA 測定系検証実験原理及び結果

Fig. 5. Result of the inspection of ELISA method on fluid filter

り，バックグラウンドの低減は可能であると考えている。

〈5·2〉 フィルター表面固定化抗体と, サンプル（マウ ス $\lg G)$ との反応時間検討結果 マウス $\operatorname{IgG}$ を添加する 際, マウス $\operatorname{IgG}$ との反応時間を $0,5,15,60$ 分と変化させ, $37{ }^{\circ} \mathrm{C}$ で反応させた。反応時間が 15 分の場合と 60 分の場 合とで吸光度の值がほぼ同一となった（図 6)。これは，フ イルター表面に固定化された抗体と,サンプル (マウス IgG) との反応が平衡状態に達したことを示唆するものである。 96 穴マイクロタイタープレートを用いた測定系では, 通常 1 時間程度の反応時間を必要とする。これは, 上述で説明し た反応槽の微小化による反応時間の短縮効果の結果である と考えることが出来る。以上の結果より, 固相抗体とサン プルとの反応時間は 15 分までで平衡状態となり, 既存の方 法上り反応時間が 60 分から 15 分へと 4 分の 1 に短縮され ることが示唆された。今後サンプル溶液を,フィルターを介 して上下にミキシングを行うなどして固相表面の抗体とサ ンプルの接触する確率を増やすことにより, 更なる反応時 


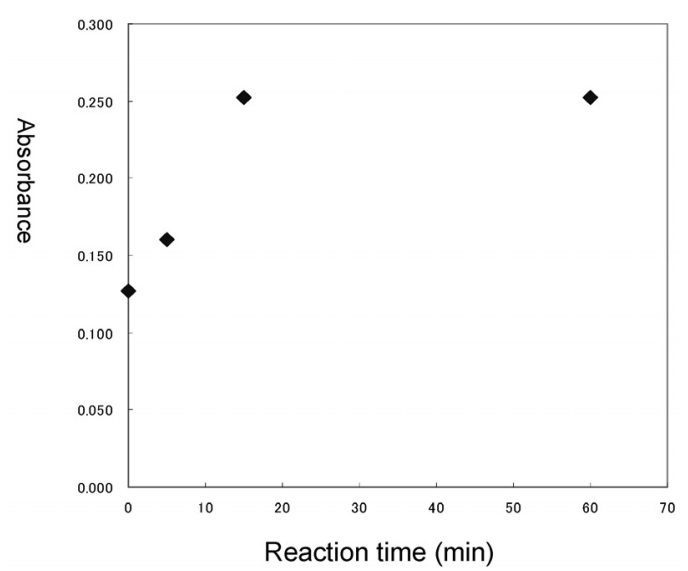

図 61 次抗体と被検物質との反応時間検討結果

Fig. 6. Time course of antigen-antibody reaction of mouse IgG with anti-mouse $\mathrm{IgG}$ fixed on fluid fiter (the first reaction)

間の短縮化を行うことは十分に期待できる。

〈5・3〉 サンプル（マウス IgG） と酵素標識 2 次抗体と の反応時間検討結果 マウス IgG $50 \mu \mathrm{l}$ を添加し, 反応終 了後, 洗浄を行い, 酵素標識抗マウス $\operatorname{IgG}$ との反応時間を $15,30,60,120$ 分と変化させた。その結果, 反応時間が 30 分 でほぼ飽和状態となることが分かった（図 7)。この結果も $\langle 5 \cdot 2\rangle$ 節の検討結果と同様に, サンプルと酵素標識 2 次抗 体との反応が平衡に達したことを示唆するものである。ま た同様に 96 穴マイクロタイタープレートを用いた測定系で は通常 1 時間程度の反応時間を必要とすることより, 反応 時間の短縮化は, サンプルと酵素標識 2 次抗体との反応に おいても反応槽の微小化による反応時間の短縮効果である と考えられる。酵素標識 2 次抗体の濃度を上げれば更に反 応時間が短縮化されることも考えられるが， ELISA 測定系 では酵素標識 2 次抗体の濃度を上げると, 固相表面への非 特異的な吸着が起こり，ノイズが増えるという問題を生ず る可能性があるため, 更に酵素標識 2 次抗体の濃度を上げ て大幅な反応時間の短縮化を行うのは困難であると考えら れる。しかし, 流体フィルターの上下で, 溶液をミキシン グすることにより, サンプルとの接触効率が高まるため, 反応時間の短縮化が期待できる。

$\langle 5 \cdot 4\rangle$ 検量線検討実験 マウウ $\operatorname{IgG}$ 濃度が $0 \sim 100$ $\mathrm{ng} / \mathrm{ml}$ の間で良好な検量線を引くことが出来た（図 8)。更に 高濃度側, 低濃度側共に, どの程度の濃度範囲まで測定で きるか今後検討する必要があるが，96 穴マイクロタイター プレートを用いた HRP を標識酵素, TMBZ を発色基質とし て使用する ELISA 法によるマウス $\operatorname{IgG}$ の測定レンジが数百 $\mathrm{ng} / \mathrm{ml}$ から数 $\mathrm{ng} / \mathrm{ml}$ 程度であることより, 図 8 に示寸検量線 の形状から推察すると, 感度面では従来法（96 穴マイクロ プレートを用いた ELISA 法) と同等であると考えられる。

\section{6. まとめ}

本研究では, 垂直方向に流路を形成した積層型マイクロ リアクターを用いて, 酵素免疫測定法（ELISA 法）を原理

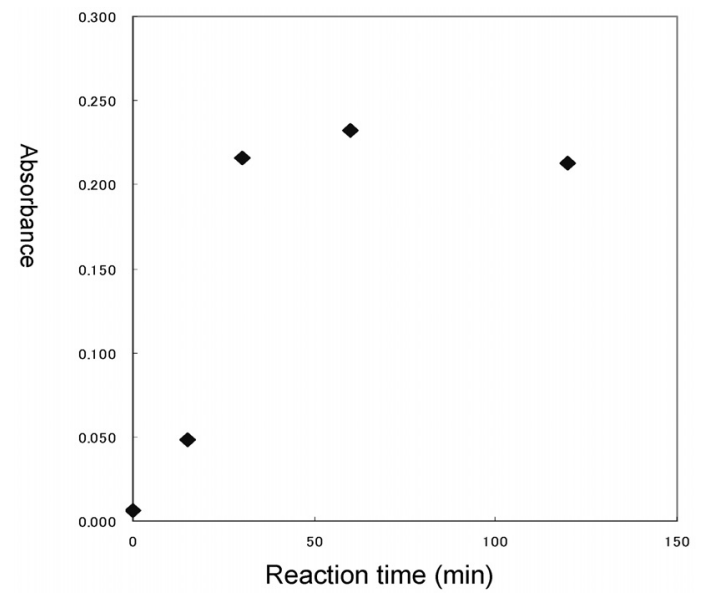

図 7 被検物質と酵素標識 2 次抗体との反応時間検討結果

Fig. 7. Time course of antigen-antibody reaction of enzymelabeled anti-mouse $\operatorname{IgG}$ with mouse $\operatorname{IgG}$ fixed on fluid filter (the second reaction)

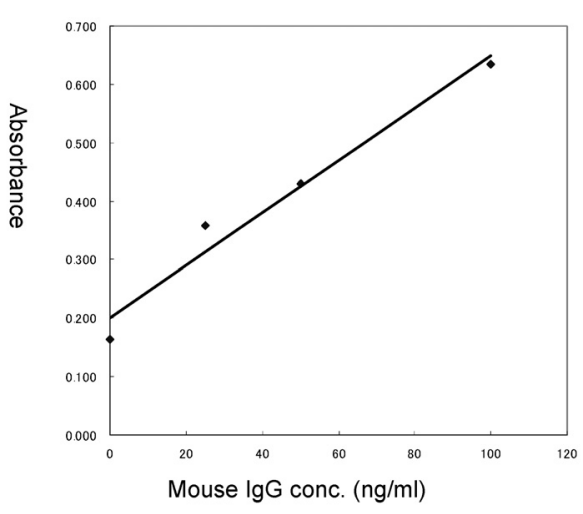

図 8 マウス $\operatorname{IgG}$ 検量線結果

Fig. 8. Calibration curve of Mouse IgG

とした抗原検出の検討を行った。本研究にて得られた知見 を以下にまとめる。

（1）放射光を用いて微細加工を行った PMMA 製フィル ターに抗体を固定化し, 酵素免疫測定法によって抗原検出 が可能であることを確認した。

（2）PMMA 製フィルターを用いた酵素免疫測定法にて 抗原を測定することにより従来法と比較して総反応時間が 120 分から 45 分に短縮寸ることが出来た。

(3) マウス IgG を測定する系では, 従来法と比較して感 度面でほぼ同等の性能を有することを確認した。

以上の検討結果から, 本マイクロリアクターを用いて, 臨 床検查・環境分析分野等への幅広い応用が可能となること が期待される。

(平成 18 年 5 月 26 日受付)

\section{文献}

(1) J. Grimwood and J. Schmutz : "Six is Seventh", Nature, Vol.425, No.23 Oct, pp.775-776 (2003)

(2) M. A. Buns, B. N. Johnson, S. N. Brahmasandra, K. Handique, J. R. Webster, M. Krishman, T. S. Sammarco, P. M. Man, D. Jones, D. 

DNA Analysis Device”, Science, Vol.282, pp.484-487 (1998)

( 3 ) T. Vilkner, D. Janasek, and A. Manz : "Micro Total Analysis Systems. (2004)

(4) T. R. Golub : "Molecular classification of cancer: class discovery and class pp.531-537 (1999)

( 5 ) K. R. Kozak, M. W. Amneus, S. M. Pusey, F. Su, and M. N. Luong : (2003)

(6) T. Asano, Y. Ukita, Y. Utsumi, K. Matsui, M. Takeo, and S. Negoro : (2005)

( 7 ) Y. Utsumi, T. Asano, Y. Ukita, K. Matsui, M. Takeo, and S. Negoro : "A Operation", Jpn. J. Appl. Phy., Vol.44, No.7B, pp.5707-5710 (2005)

( 8 ) Y. Utsumi, T. Kishimoto, T. Hattori, and H. Hara : "Larage-Area X-ray (2005)

(9) Y. Utsumi and T. Kishimoto : "Large area and wide dimension range x-ray and Technology, B 23 (6), pp.2903-2909 (2005)

(10) H. Suzuki, K. Fukushima, M. Matsuo, N. Hashimoto, and N. pp.1169-1174 (1996)

(11) V. V. Padhye, T. Zhao, and M. P. Doyle : "Production and characterization pp.219-226 (1989)

松 井 勝 弘

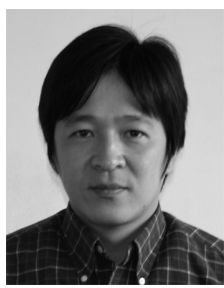

森 本 祥 平

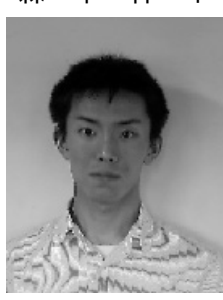

浅 野 豪 文

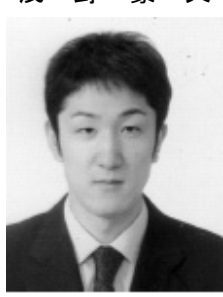

Heldsinger, C. H. Mastrangelo, and D. T. Burke : “An Integrated Nanoliter Recent Developments", Analytical Chemistry, Vol.76, pp.3373-3386 prediction by gene expression monitoring", Science, Vol.286, No.5439, "Identification of biomarkers for ovarian cancer using strong anion-exchange Protein Chips: Potential use in diagnosis and prognosis", Proc. of the National Academy of Sciences, Vol.100, pp.12343-12348 "Vertical Micro Reactor Stack for Integrated Chemical Reaction System", e-Journal of Surface Science and Nanotechnology, Vol.3, pp.190-194 New Micro-Chemical Reactor Using Fluid Filters for Vertical Fluid Flow Lithography System for LIGA Process Operating in Wide Energy Range of Synchrotron Radiation", Jpn. J. Appl. Phys., Vol.44, No.7B, pp.5500-5504 lithography for lithographite, galvanoformung, and abformung process using energy bariable synchrotron radiation", Journal of Vaccum Science Yoshihara : "Detection of HIV-1 in plasma samples using microplate hybridization after RT-PCR", Rinsho Byori, 1996 Dec, Vol.44 No.12, of monoclonal antibodies to Verotoxins 1 and 2 from Escherichia coli of serotype O 157: H7", Journal of Medical Microbiology, Nov, Vol.30, No.3,

浮田芳 昭

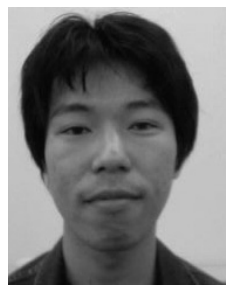

(学生員) 1982 年生。 2006 年 3 月兵庫県立大 学大学院工学研究科機械系工学専攻博士前期 課程修了。現在, 兵庫県立大学大学院工学研究 科機械系工学専攻博士後期課程在学中。

加 藤 太一郎 (非会員) 1977 年生。2000 年 3 月慶應義塾大

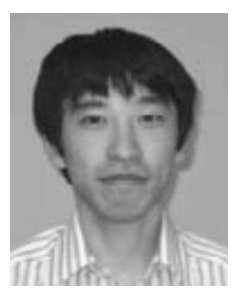

学理工学部化学科卒業。2002 年 3 月慶應義塾大 学大学院理工学研究科基礎理工学専攻前期博 士課程, 2005 年 3 月同大学院後期博士課程修 了。博士(理学)。2005 年 4 月日本学術振興会特 別研究員(京都大学化学研究所), 同年 10 月兵庫 県立大学大学院工学研究科物質系工学専攻助 手。生体触媒・酵素を用いた有用物質の生産技 術の開発と酵素の有する高い立体選択性の解明を研究テーマに研 究・教育に従事。

武 尾 正 弘 (非会員) 1963 年生。1986 年 3 月大阪大学工

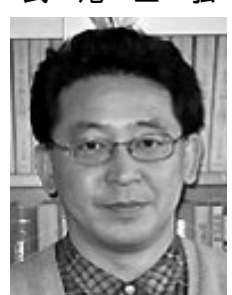
学部環境工学科卒業。1988 年 3 月大阪大学大学 院工学研究科博士前期課程環境工学専攻修了。 1988 年 4 月日清食品(株)。1991 年 7 月姫路工業 大学工学部助手, 2000 年 10 月同講師を経て, 2004 年 4 月兵庫県立大学大学院工学研究科物 質系工学専攻助教授。工学博士 (大阪大学)。 2000 年 9 月〜2001 年 8 月ドイツ・シュツッツ ガルト大学客員研究員。環境污染物質の微生物分解機構の解明と環 境浄化及び分析技術の開発を研究テーマに研究・教育に従事。 学繊維学部高分子学科卒業。1996 年 3 月神戸大 学大学院自然科学研究科博士前期課程生物学 専攻修了。同年シスメックス(株)（旧名：東亞 医用電子(株)）入社。現在, 社会人博士課程学 生として兵庫県立大学大学院物質系工学専攻 博士後期課程に在籍中。

（非会員） 1984 年生。2006 年 3 月姫路工業大 学工学部応用化学科卒業。現在, 大阪大学大学 院生命先端工学専攻博士前期課程に在籍中。

（非会員） 1981 年生。 2006 年 3 月兵庫県立大 学大学院工学研究科機械系工学専攻博士前期 課程修了。現在, 総合研究大学院大学物理化学 研究科構造分子科学専攻博士後期課程在籍中。 